\title{
YUMURTA AKININ PIA, ARAKNOID VE DURA TAMIRINNDE KULLANIMI; DENEYSEL ÇALIŞMA
}

\section{Using of Chicken Egg White for Pia, Arachnoid and Dura Repair: An Experimental Study}

\author{
Adnan ALTUN ${ }^{1}$, Cengiz ÇOKLUK ${ }^{2}$ \\ ${ }^{1}$ KTO Üniversitesi Tıp Fakültesi, Beyin ve Sinir Cerrahisi A.D., KONYA, TÜRKIYYE \\ ${ }^{2}$ Ondokuz Mayıs Üniversitesi Tıp Fakültesi Beyin ve Sinir Cerrahisi A.D., SAMSUN, TÜRKIYE
}

Amaç: Nöroşirürjikal temel cerrahi girişimler santral sinir sistemini çepeçevre saran pia - araknoidal ve dural zarların uygun bir şekilde açılmalarını ve cerrahi girişimin tamamlanmasını takiben de sıvı sızdırmaz olarak kapatılmasın gerektirir. Bu çalışmanın temel amacı pia -arachnoidal ve dural zarların onarılmasında ovalbumin ve ovamucoid içeriği zengin yumurta beyazının kullanılabilirliğinin incelenmesidir.

Gereç ve Yöntemler: Bu deneysel çalışmada 4 adet taze dana beyni kadavrası kullanıldı. Beyinlerin frontal ve parietal loblarında dura 2 santimetre kadar kesilerek toplam 16 adet kesi alanına yumurta akı dura kesisi üzerine ince bir şerit olarak uygulandı. Aynı işlem pia-araknoid zar için yapılan 1.5 $\mathrm{cm}$ kesiler için yapıldı. Yumurta akının koagulasyonu ile yapıştırılan kesi alanlarından ince kesitler alınarak histopatolojik olarak incelendi. Dura ve pia-araknoid zarın üstüne uygulanan yumurta akının koagulasyon sonrasında su geçirmezliği ise mikroksop altında yapılan mekanik testler ile değerlendirildi.

Bulgular: Histopatolojik incelemeler de kesi alanına tatbik edilen yumurta akında bulunan ovalbumin ve ovamukoid proteinlerinin koagulasyonunun kesilen beyin zarlarında yapıştırıcı etkisinin olduğu gösterildi. Ayrıca yumurta akı içeriklerinin fibroz dokulara yapışarak koruyucu özellik sağladığ gözlendi.

Sonuç: Bu deneysel eğitim modelinin, beyin cerrahisinde dura ve pia-araknoid onarımda katkı sağlayacağını düşünmekteyiz. Ayrıca yumurta akı üzerinde yapılacak çalışmaların gelecekte doku yapıştırıcısı, mekanik bariyer ve doku tamiri için sistemlerin gelişmesine katkıda bulunabileceğini düşünmekteyiz. Ancak klinik pratikte yumurta akı içeriklerinin yer alabilmesi için oldukça detaylı histopatolojik ve biyokimyasal çalışmaların canlı deney hayvanları üzerinde yapılmasına ihtiyaç duyulmaktadır.

Anahtar Kelimeler: Dura onarımı, pia-araknoid onarımı, yumurta beyazl, ovalbumin, ovamukoid
Objective: Basic surgical procedures in neurosurgery require proper opening of the pia-arachnoidal and dural membranes surrounding the central nervous system and then the completion of the surgical procedure followed by watertight closure. The main purpose of this study was to examine the usability of ovoid and ovamucoid rich egg whites in the repair of pia-arachnoidal and dural membranes.

Material and Methods: In this experimental study, 4 uncovered fresh cadaveric calf brains were used. In the frontal and parietal lobes of the brains, dura was cut by 2 centimeters and the egg white was applied on a total of 16 dura incision areas as a thin strip. The same procedure was also performed for 16 incision sites of the pia-arachnoid membrane that was cut by 1.5 centimeters. Thin sections were taken from the incised and egg white applied areas and examined histopathologically. After coagulation of the egg whites applied on the dura and pia-arachnoid membranes, the water resistance was evaluated mechanically and histopathologically.

Results: Histopathological examinations showed that ovalbumin and ovamucoid found in the egg white had an adhesive effect on the brain membranes. It was also observed that the egg white contents provided protective properties by adhering to the fibrous tissues and prevented the fluid passage in mechanical tests.

Conclusion: We think that this experimental training model will contribute to dura and pia-arachnoid repair in neurosurgery. In addition, we believe that oncoming studies on egg whites may contribute to the development of systems for tissue glue, mechanical barrier and tissue repair in the future. But, in order to include egg white contents in clinical practice, detailed histopathological and biochemical studies are needed to be performed on live experimental animals.

Keywords: Dura repair, pia-arachnoid repair, egg white, ovalbumin, ovamucoid 


\section{GíRiș}

Santral sinir sistemine yönelik cerrahi girişimler bu sistemi çepeçevre saran pia-araknoid ve dural tabakaların patolojiye en yakın bölgeden kesilerek açılmalarını gerektirir. Patolojiye yönelik spesifik cerrahi girişim tamamlandıktan sonra nöroanatomik ve nörofizyolojik işlevleri olduğu bilinen bu zar tabakalarının uygun bir şekilde kapatılarak onarılmasını gerektirir. Bu işlem yapılmadığı takdirde beyin omurilik sıvısı kaçağı ve bununla ilişkili komplikasyonlar başta olmak üzere pek çok olumsuz durum ile karşıllaşılacaktır (1,2). Cerrahi pratik açısından bakıldığı zaman Pia Mater in onarılması veya kapatılması kolay bir işlem olmayıp pek çok yönüyle mümkün olmamaktadır. Araknoid mater ise bazı uygun durumlarda ince cerrahi sütür veya diğer bazı teknikler kullanılarak kapatılabilir ve bu şekilde beyin ve omurilik sıvısının dolaşımı normal anatomiye yakın bir şekilde sağlanabilir. Dura mater ise tüm bu sistemi en dış tarafından çepeçevre saran temel zar tabakasıdır. Ameliyatlardan sonra bu tabakanın uygun bir şekilde beyin omurilik sıvısnı kaçırmayacak şekilde kapatılması gerekmektedir.

Uygulanan cerrahi girişimlerden sonra dura materin kapatılması işlemi devamlı veya tek tek sütür konularak su geçirmez şekilde dikilerek yapılmaktadır. Bazı hastalarda dura materin bu şekilde kapatılması mümkün olmamaktadır. $\mathrm{Bu}$ olgularda dikilebilen organik veya sentetik dura materyalleri greft olarak kullanılmaktadır. Yine bazı hastalarda beyin omurilik sıvısı sütür aralıklarından sızma şeklinde epidural mesafeye kaçmaktadır. Klinik pratikte bu kaçışın engellenmesi için doku yapıştırıcısı gibi kan ürünlerinden elde edilen materyaller bir seçenek olarak kullanılabilir. Bu materyallerin kullanılması bir hazırlık aşaması gerektirmektedir. Ayrıca saha büyüklüğü göz önüne alındığı zaman kullanılacak materyalin fazla olmasını gerektirir. Bu materyal fibrin içeriği ile donmakta ancak biyomekanik olarak güçlü bir bariyer görevi görmemektedir. Bu nedenle dura üzerine tatbik edilen bu ve benzeri materyallerin biyomekanik mikrotravma etkileriyle beyin omurilik sıvısı kaçağına önlemekte yetersiz kalabileceği düşünülmektedir.

$\mathrm{Bu}$ deneysel çalışmada pia-araknoid ve dura mater onarımında yardımcı olması amacıyla tatbik edilmesi kolay olan yumurta akı maddesi kullanılmıştır. $\mathrm{Bu}$ madde ince film tabaka şeklinde dura ve pia-arachnoid mater üzerine tatbik edilmiş daha sonra bipolar ile koagule edilerek ısıya maruz bırakılmıştır. Bu deneysel çalışmanın primer amacı bu materyalin nöroanatomik zarları onarılmasını katkı sağlayabilirliğinin deneysel olarak incelenmesi ve biyolojik membranlar ile biyomekanik olarak etkileşiminin literatür eşliğinde araştırılmasıdır.

\section{GEREÇ VE YÖNTEM}

\section{Yumurta Akının Deney için Hazırlanması}

Yumurta akı maddesinin deneysel inceleme için hazırlanması oldukça basit bir işlemdir. Yumurta kabuğu açılmakta, 10 cc enjektör aracılığı ile yumurtanın beyazı enjektörün içne çekilmektedir. Bu işlem sonrasında materyal kullanıma hazır hale gelmektedir. $\mathrm{Bu}$ işlem ardından hasarlı beyin zarına yumurta akı uygulayıp bipolar ile koagula edilerek hasarlı kısmın onarılması amaçlanmaktadır (Şekil 1).

\section{Taze Dana Kadavra Beynin Hazırlanmast}

Sığır popülasyonu besin maddesi olarak kullanılmakta ve baş kısmı genellikle ayrılmaktadır $\mathrm{Bu}$ nedenle kent mezbahanelerinden temin edilmeleri çok kolaydır. Bu çalışmada kullandığımız deneysel girişim için 4 adet dana kafası hazırlanmış ve dura mater ile beyin dokusu birlikte kalacak şekilde kemik yapının frontal ve parietal kemik dokusu tamamen uzaklaştırılmıştır. Deneysel çalışmada bu yumuşak doku materyali işlem için kullanılmıştır. 




Şekil 1: Hasralı beyin dokusu üstüne yumurta akının uygulanıp bipolar ile koagulasyonunun illüstrasyonu (Prof. Dr. Cengiz ÇOKLUK tarafından illüstre edilmiştir)

\section{Deney Yöntemi}

Dış ortamda yumurta akının bipolar ile 15, 20, 25 ve 30 watt uygulandığında 2 ile 4 sn arasında koagule olup katılaştığı gözlendi. Yapılacak deneyde zaman faktörünün değişken faktor olmaması için koagulasyon süresi 3sn olarak belirlendi.

\section{Dura Mater için Yapılan Deney}

Deneysel girişim için 4 adet taze dana beyninin sağ ve sol frontoparietal bölgesi kullanıldı.

$\mathrm{Bu}$ deneysel çalı̧̧ma operasyon mikroskobu altında gerçekleştirildi. Her taze kadavranın pariyatal ve frontal loblarında dura üstünde 15 nolu bistüri ile $2 \mathrm{~cm}$ kesiler oluşturuldu (Şekil 2a). Her kadavranın sağ ve sol frontal ve parietal lobları kullanıldığı için bir kadavrada 4 kesi, 4 kadavrada toplam 16 kesi oluşturuldu. Mikro Adson dişli penset yardımı ile dura yaprakları birbirine değecek şekilde yanaştırıldı.10 cc ejektöre çekilen yumurta akı, enjektör ucu ile ince bir zar oluşturacak şeklide duranın üstüne yayıldı (Şekil 2b). Birinci kadavrada bipolar ile yumurta akına 15 watt güç 3 sn uygulanarak koagule edildi ve yumurta akının katılaştığı gözlendi.

İkinci kadavrada yumurta akına 20 watt, 3. Kadavrada 25 watt ve 4 . kadavrada 30 watt güç 3 sn uygulandı. Böylece her kadavrada yumurta akı verilen güç oranında hızlı bir 1sıl işlemden geçtiği için yumurta akı proteinleri denatüre edilmiş oldu ve duranın kesik olan yüzeyinde katılaştı.

20 cc'lik enjektöre çekilen Serum Fizyolojik duranın altına sokularak yavaş yavaş dura altında enjekte edildi (Şekil 3a). Medson makas ile enjektörün girdiği delikten ilerlenerek duranın yapıştırılan bölgesine içeriden dışarıya doğru güç uygulandı (Şekil 3b). Alınan 16 spesmen histopatolojik incelemeye gönderildi. 


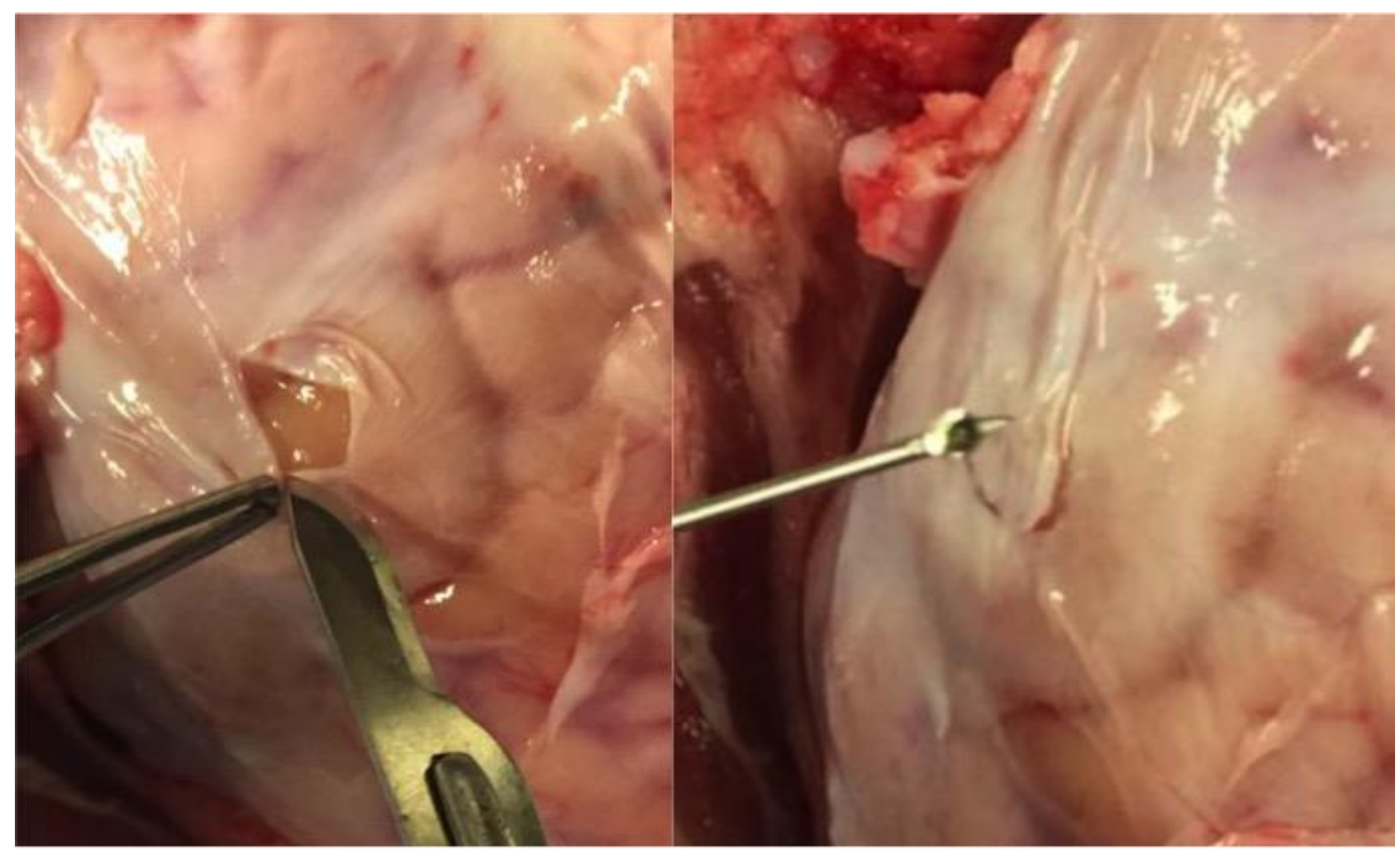

Şekil 2a: taze kadavra dana beyninde dura membran insizyonu.

2b: dura membranının insizyonu üzerine yumurta akının ince zar şeklinde uygulanması

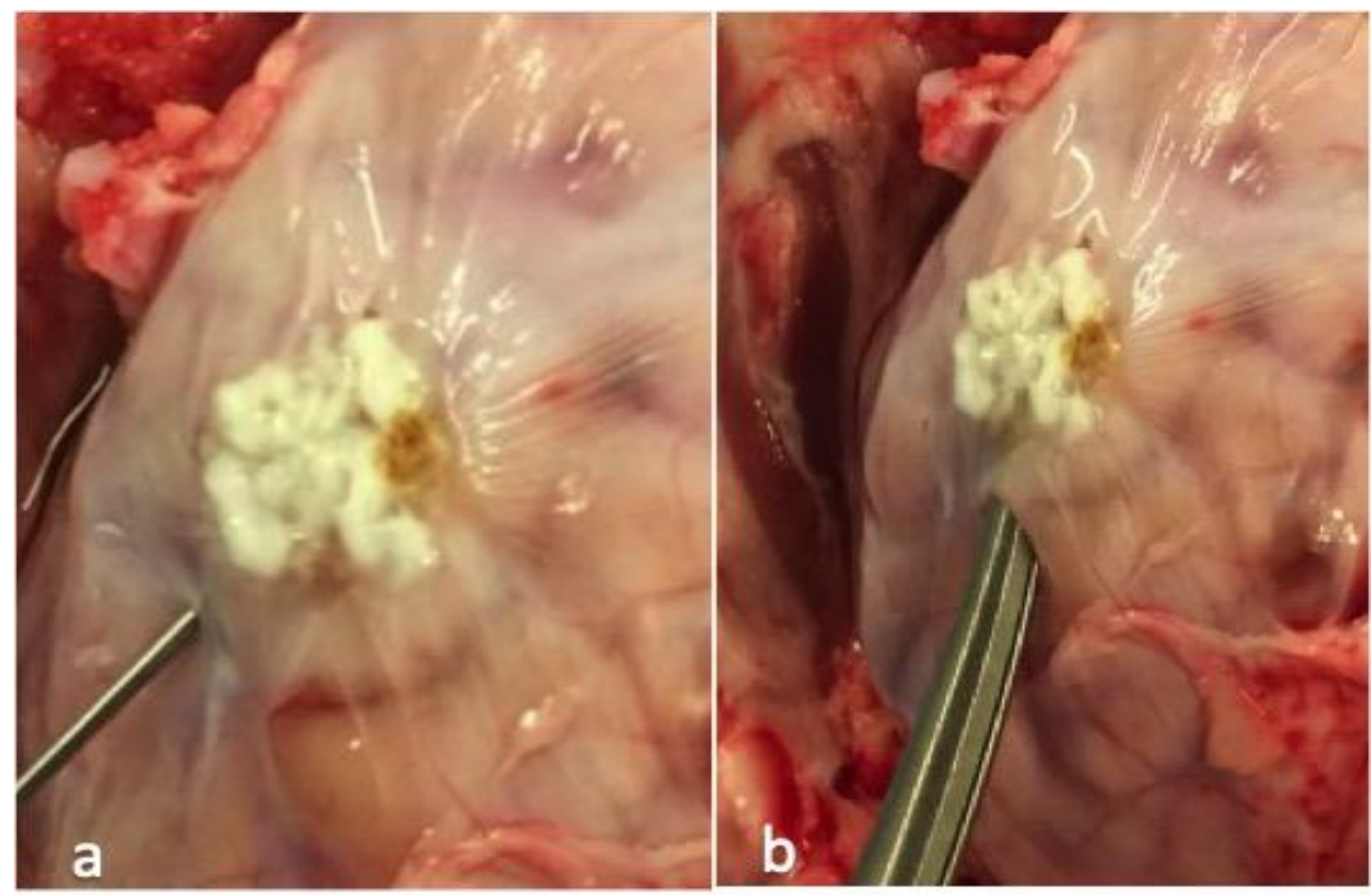

Şekil 3a: Enjektör ile dura altına serum fizyolojik tatbiki sonucu su sızdırmazlı̆̆ının mekanik testi.

3b: Medson makas ile duranın içeriden yukarıya itilmesini gösteren mekanik dayanıklık testi 


\section{Pia-Araknoid Mater için Yapılan Deney}

Taze kadavraların duraları uzaklaştırıldıktan sonra her kadavranın her iki hemisferinde 4 adet 15 nolu bistüri ile mikroskop altında $1,5 \mathrm{~cm}$ kesiler halinde piaaraknoid membran birlikte açıldı ve parankimden diseke edildi. Mikro Adson dişli panset yardımı ile piaaraknoid zarların kesik yaprakları birbirine yanaştırıldı (Şekil 4a,4b). 10 cc ejektöre çekilen yumurta akı, enjektör ucu ile ince bir zar oluşturacak şeklide piaaraknoid üstüne yayıldı. Zarın çok ince olması nedeniyle yüksek watt uygulandığında ortamın koagule olduğu ve pia-araknoid yapının parankime doğru hasarlandığı gözlemlendiğinden bütün kadavralarda 15 watt uygulanmasına karar verildi. Bütün kadavrada bipolar ile yumurta akına 15-watt güç 3sn uygulanarak koagule edildi ve yumurta akının kesik araknoid üzerinde katılaştığı gözlendi (Şekil 5a). 5 cc'lik enjektöre çekilen Serum Fizyolojik, pia-araknoid altına sokularak yavaş yavaş enjekte edildi (Şekil 5b). Alınan 16 spesmen histopatolojik incelemeye gönderildi.
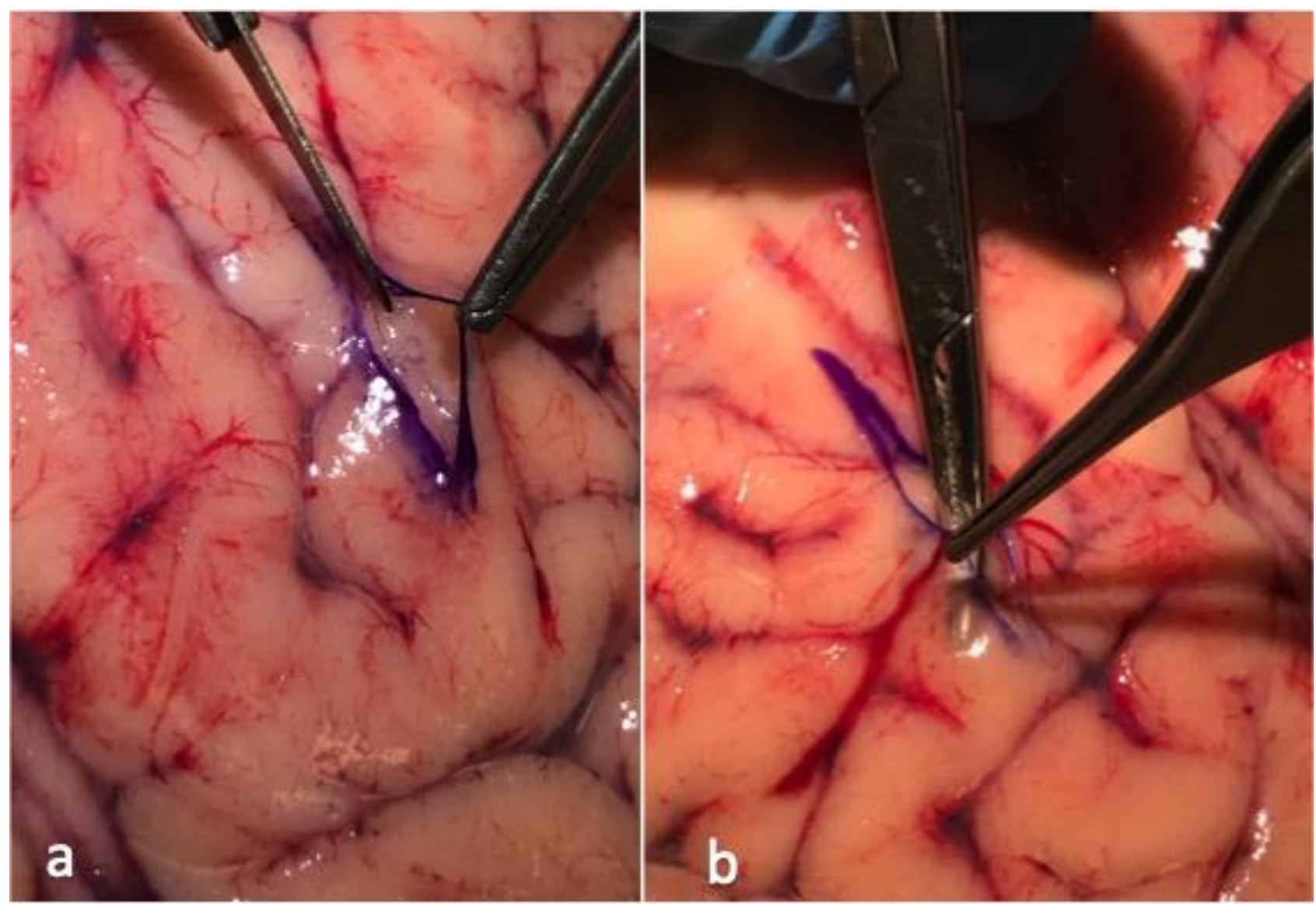

Şekil 4a: Pia-araknoid membran insizyonu. 4b: Pia-araknoid membranın beyin parankiminden diseksiyonu 


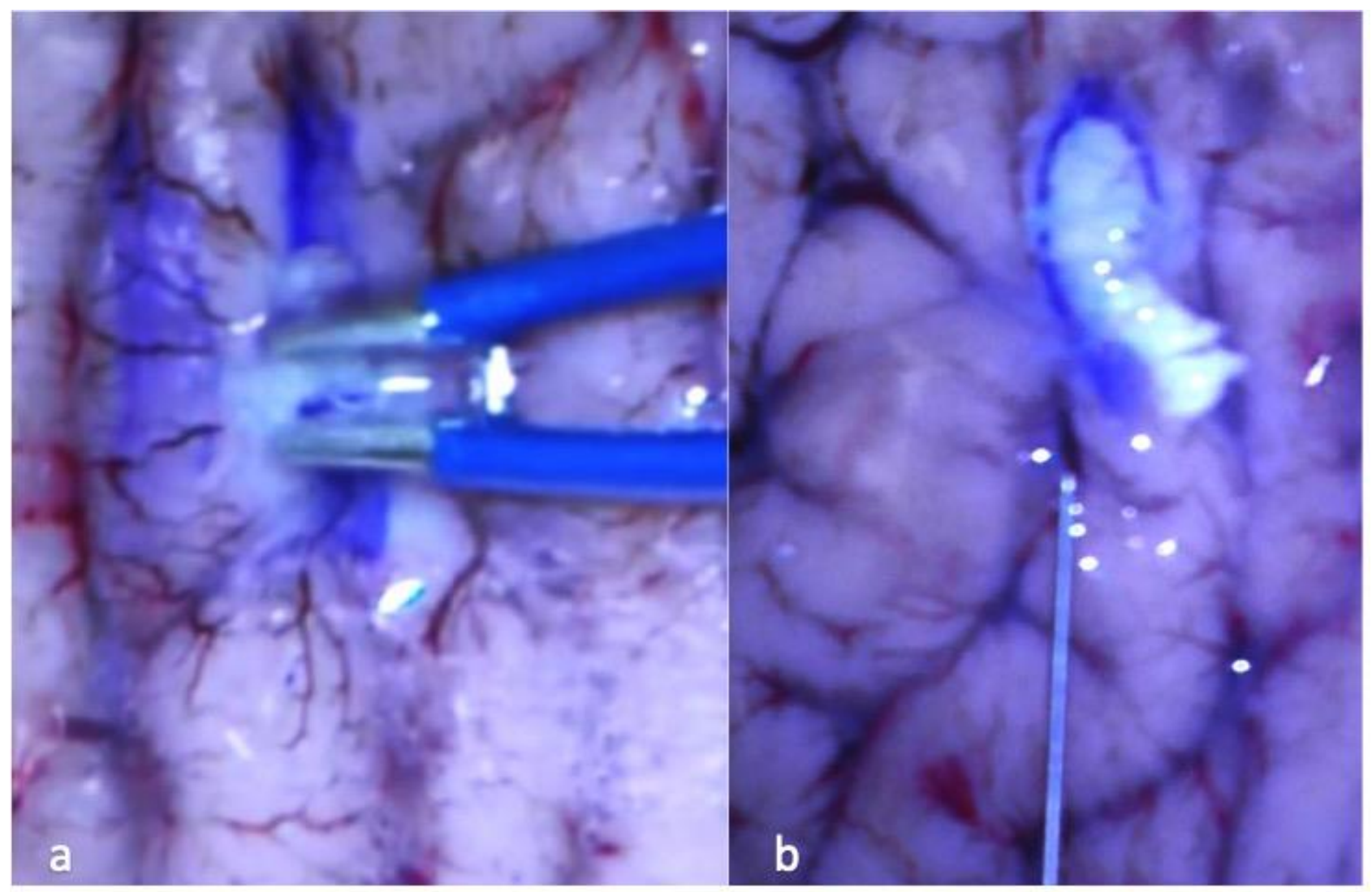

Şekil 5a: Pia-araknoid membran üsütndeki yumurta akının koagulasyonu.

5b: enjektör ile pia-araknoid membran altına serum fizyolojik tatbiki sonucu su sızdırmazlığının mekanik testi

\section{BULGULAR}

\section{Dura Mater}

Duranın kesi yüzeyine yumurta akı ince şerit olarak sürüldükten sonra her kadavrada bipolar farklı watt gücünde 3 sn olacak şekilde uygulandı. Mikroskop altında serum fizyolojiğin duranın altına enjekte edildiğinde dura materin yukarı doğru bombeleştiği ve bütün kesilerde sıvı sızdırmaz olduğu gözlendi. Buda sıv1 sızdırmazlığının akımın gücüyle bağlantılı olmadığını, yumurta akının koagule edilip katılaştıktan sonra dura kesisi üstünde yapışarak bütünlük oluşturduğunu gösterdi.

Mikrodisektör ile duranın altına girildikten sonra yukarı doğru itildiğinde duranın hemen ayrılmadığı gözlendi. Kuvvet giderek arttrrılınca yapışma yerinden hafifce ayrıldığı gözlendi. Ayrıca mekanik testte 25 ve 30 watt uygulanan kesilerde daha az dayanıklığı olduğu fark edildi. Bu durumun yumurta akındaki proteinlerin yüksek 1sıda hızlı denature olduğu için yapışma özelliğini yitirmesinden dolayı olduğu düşünüldü.

Histopatolojik incelemde dura kesisi üzerinde oluşmuş, kaplayıcı membran yapısı gözlendi.

Histopatolojik incelemelerde dura tabakalarının yumurta akı maddesi kullanılan bölgede düzgün bir şekilde karşıllklı olarak durduğu ve bu membranlar üzerinden ince bir tabaka şeklinde tatbik edilen materyalin oluşturduğu membran saptandı (Şekil 6a).

\section{Pia-Araknoid}

Araknoid kesilerinde bipolar ile 15 watt gücünde koagulasyon yapıldı. Mikroskop altında sızdırmazlığ test edildi ve 16 kesinin 14'ünde sızdırmaz olduğu gözlendi. Sadece 2 keside serum fizyolojik verildikten sonra hafif sızdırdığı gözlendi. Bunun pia-araknoid membranın yapısının çok ince olması ve 
koagulasyonun membrana hasar vermesinden

kaynaklandığ 1 düşünüldü.

Pia-araknoid membran çok narin olduğundan mikrodisektör güç testi yapılamadı.

Histopatolojik incelemeler gözlemlendiğinde; piaaraknoid mater tabakalarının yumurta akı maddesi kullanılan bölgede düzgün bir şekilde karşılıklı olarak durduğu ve bu membranlar üzerinden ince bir tabaka şeklinde tatbik edilen materyalin oluşturduğu membran saptanmıştır (Şekil 6b).

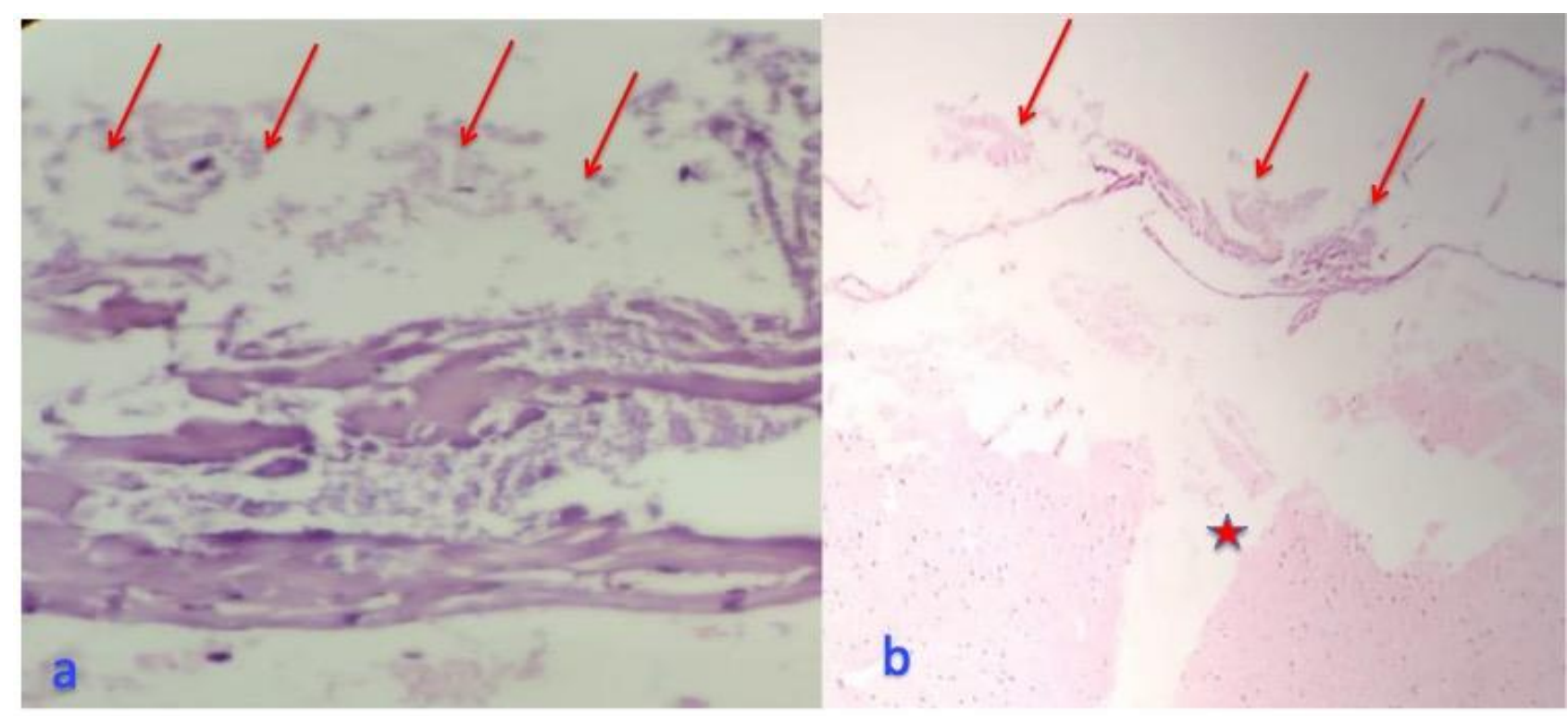

Şekil 6a: Duranın üzerindeki yumurta akının koagulasyonu sonucunda oluşan bariyerin histopatolojik gösterimi. 6b: Pia-araknoid membran üzerindeki yumurta akının koagulasyonu sonucunda oluşan bariyerin histopatolojik gösterimi oklar: koagule olan yumurta proteinlerinin oluşturduğu bariyer, yıldız: pia-araknoid membrane kesimi esnasında oluşan parankim kesi alanı

\section{TARTIŞMA}

$\mathrm{Bu}$ deneysel çalışma pia- araknoid ve dura mater gibi santral sinir sistemini çepeçevre saran zar tabakalarının cerrahi girişim sonrasında güçlü bir şekilde onarım işlemi için ovalbumin (toplam proteinin yaklaşık \%55'ini oluşturur ve depolama proteini olduğu varsayılır) ve ovamucoid (yumurta akının jel oluşumunu sağlar, sıcaklığa ve enzimlere karşı stabil bir yap1 oluşturur) içerikten zengin yumurta ak1 maddesinin kullanılabilirliğinin incelenmesi amacıyla birinci basamak fresh cadaverik deneysel çalışma olarak dizayn edilmiştir $(3,4)$. Bu çeşit çalışmalar biyolojik bir organizmada fonksiyonel bir iyileşmenin incelenmesi amaciyla uygun olmaktan öte biyomekanik ve kullanılabilirliğinin araştırılmasını uygun olarak dizayn edilmiştir. Bulunma kolaylığı ve etik olarak uygun olması nedeniyle taze sığır beyni kadavrası kullanılmıştır $(5,6)$. Büyüklük açısından beyin dokusu insan beyninden oldukça küçük ancak histopatolojik inceleme yönünden birbirine benzer özellikler taşımaktadır. Dolayısıyla yukarıda söylenen avantajlarından dolayı bir model olarak sı̆̆ır beyninin kullanılması tercih edilmiştir $(6,7)$. İşlem sonrası değerlendirmeleri biyolojik bir yaranın iyileşmesi özellikleri dışında biyomekanik ve nöroanatomik bütünlüğün korunması yönleriyle değerlendirmeler yapılmıştır. 
Günlük nöroşirurjikal girişimler santral sinir sistemi içerisinde yerleşik patolojilerin ortadan kaldırılması veya biyopsi işlemleri için uygulanmaktadır. $\mathrm{Bu}$ işlemler sırasında öncelikle en dışta bulunan kafatası kemiği açılmaktadır. Patoloji üzerindeki dura mater makas ile kesilmekte daha sonra da ortaya çıkan pia ve araknoid kesilmekte ve patolojik dokuya ulaşılmaktadır. Bu cerrahi girişimler nöroanatomik ve fizyolojik olarak pek çok görev üstlenen bu membran tabakalarının bütünlüklerinin bozulması anlamına da gelmektedir. Cerrahi işlem sonrasında nöral doku da ulaşacak yapışıklıkların önlenmesi ve santral sinir sistemi içerisinde dolaşımsal olarak fonksiyon gösteren beyin omurilik sıvısının dışarıya kaçışının kesilmesi amacıyla bu üç tabakalı membran yapısının korunması gereklidir (8).

Cerrahi pratikte pia-mater tabakasının dikilmesi veya onarılması tekniği bulunmamaktadır. Bizim kullandığımız deneysel girişimde; uygulanan Sıv1 materyal cerrahi alana sürülerek kortikal split yapılan pia-mater bölgesi'nin kapatılmasını mümkün hale getirmiştir. Klinik pratik açısından düşünüldüğü zaman ovomucoid sıvı içerisinde bulunan alerjik maddeleri uzaklaştırılması işlemi yapılmalıdır $(3,4)$. Bazı literatür çalışmalarında ısı etkisiyle alerjen etkisi bulunan bu maddelerin işlevlerine kaybettiği bildirilmiştir (3). Dolayısıyla bu deneysel çalışmada yumurta ak1 maddesi sürüldükten sonra koagule edilmesi alerjik maddelerin etkisiz hale gelmeleri ve aynı zamanda 1sı etkisiyle maddenin organik tabakalara yapışması sağlanmaktadır. Histopatolojik veriler göz önünde bulundurulduğunda nöral dokudaki hasarın ve yırtıklığın ağızlığı ve yara dudaklarının birbirine olan yakınlığı pozitif bir gözlemdir.

Araknoid tabaka bir sistern veya sulkus açıldığı zaman kapatılması önemli hale gelmektedir. Özellikle silvian sistem ve sisterna magna içerisinde yerleşik patolojilerin cerrahi işlemlerinden sonra araknoid membran dudaklarının çok ince sütür kullanılarak dikilmesi bazı cerrahi girişimlerde mümkün olurken bazı olgularda membran dokusunun oldukça ince oluşu ve dudakların birbirine yaklaşmaması nedeniyle imkânsız hale gelmektedir (9). Bu deneysel çalışmamızda araknoid membran üzerine sürülen sıvı materyal ve 1sı etkisiyle yapıştırılarak katılaştırılmış membran onarımı için ideal gibi gözükmektedir. Histopatolojik incelemelerde araknoid membran dokusunun onarılmasında yumurta akının uygun olabileceğini göstermektedir. Ancak canlı dokular üzerinde bu işlemin tekrarlanması ve süreç içerisinde membran bütünlüğünün ve fonksiyonunun kurulup kurulmadığının anlaşılması gerekmektedir.

Sonuçları açısından değerlendirildiği zaman bu deneysel çalışmanın en çarpıcı yönü dura mater üzerinde bir ince tabaka oluşturarak beyin ve omurilik sıvısının kaçışını engelleyebilecek düzeyde bir fonksiyona sahip olabileceğinin gösterilmesidir. Özellikle bu ince tabakanın posteriyor yönünden kemik yap1 ile desteklenmesi sayesinde oldukça işlevsel bir tabaka oluşturacağını düşünmekteyiz. $\mathrm{Bu}$ deneysel çalışmamızda ki histopatolojik veriler bunu kanıtlar düzeydedir. Ancak yaşayan bir organizmada bu tabakanın işlevselliğini devam ettirip ettirmeyeceği veya akibetinin ne olacağı özellikle incelenmelidir. Erken dönemde beyin omurilik sıvısı akışını engellenmesi fistül oluşumunun önlenmesi açısından önemli olarak görülmektedir. $\mathrm{Bu}$ yönüyle değerlendirildiği zaman uygulanan yumurta ak1 proteinlerinin işlevsel bir madde olma ihtimalinin oldukça yüksek olduğu ve biyomekanik dayanıklılığının sağlam olduğunu göstermektedir.

Pia-arachnoid membran ve dura membran tabakalarını cerrahi işlem sonrasında onarılması işlemi için yumurta ak1 maddesi içerisinde bulunan ovalbümün ve ovamukoid içeriğinden zengin yumurta akı maddesi kullanılmıştır. $\mathrm{Bu}$ deneysel çalışmanın sonuçları değerlendirildiği zaman bu maddenin santral sinir sistemini çepeçevre saran zar yapısının cerrahi işlem sonrasında onarılması için uygun bir materyal olacağı kanaat oluşmaktadır. Ancak klinik pratikte bu 
maddenin yer alabilmesi için oldukça detaylı histopatolojik ve biyokimyasal çalışmaların canlı deney hayvanları üzerinde yapılması gerekmektedir.

Etik kurula yapılan başvuruda, onaya gerek olmadığı kararı alınmıştır (Tarih: 13.01.2019, karar no:01).

\section{KAYNAKLAR}

1. Cokluk C, Aydin K. Maintaining microneurosurgical ability via staying active in microneurosurgery. Minim Invasive Neurosurgery. 2007;50(6):324-7.

2. Kiran NAS, Furtado SV, Hedge AS. How I do it: Anterior clinoidectomy and optic canal unroofing for microneurosurgical management of ophthalmic segment aneurysms. Acta Neurochir. 2013;155(6):1025-9.

3. Hincke MT, Nys Y, Gautron J, Mann K, Rodriguez-Navarro AB, McKee MD. The eggshell: structure, composition and mineralization. Front Biosci (Landmark Ed). 2012;17(1):1266-80.

4. Nakano T, Ikawa NI, Ozimek L. Chemical composition of chicken eggshell and shell membranes. Poultry Science. 2003;82(3):510-4.

5. Yadav YR, Parihar V, Ratre S, Kher Y, Iqbal M. Microneurosurgical Skills Training. J Neurol Surg A Cent Eur Neurosurg. 2016;77(2):146-54.

6. Altunrende ME, Hamamcioglu MK, Hicdonmez T, Akcakaya MO, Birgili B, Cobanoglu S. Microsurgical training model for residents to approach to the orbit and the optic nerve in fresh cadaveric sheep cranium. J Neurosci Rural Pract. 2014;5(2):151-4.

7. Belykh E, Byvaltsev V. Off-the-job microsurgical training on dry models: Siberian experience. World Neurosurg. 2014;82(1-2):20-4.

8. Turan Suslu H, Ceylan D, Tatarli N, Hicdonmez T, Seker A, Bayri Y et al. Laboratory training in the retrosigmoid approach using cadaveric silicone injected cow brain. $\mathrm{Br}$ J Neurosurg. $2013 ; 27(6): 812-4$

9. Spetzger U, von Schilling A, Brombach T, Winkler G. Training models for vascular microneurosurgery. Acta Neurochir Suppl. 2011;112(5):115-9. 